\title{
The Effect of the Exercise Program on Attention Deficits and Exam Anxiety Levels of Students Preparing for the LGS Exam through Distance Education during Covid-19 Pandemic Process
}

\section{Emrah Seçer $^{*}$, Nurcan Demirel ${ }^{2}$, Cemil Tuğrulhan Șam²}

${ }^{1}$ School of Physical Education and Sport, Erzincan Binali Yildirim University, Erzincan, Turkey

${ }^{2}$ Department of Sports Sciences, Atatürk University, Erzurum, Turkey

Study Area: Erzincan, Turkey

Coordinates: $39^{\circ} 44^{\prime} 47^{2}$ ?N; $39^{\circ} 29^{\prime} 29^{2}$ E

Key words: Online Stdy, E-learning, Pandemic year.

\section{Abstract}

It is thought that children are devoid of basic needs of being social, belonging to a group, etc., due to the restrictions in the Covid-19 pandemic process and this may cause some mental problems in students preparing for the exam. The aim of this study is to examine the effects of exercises to be applied during the pandemic process, which has become an international problem, on the attention deficit and exam anxiety levels of 8th-grade students who are preparing for the High School Entrance Exam (LGS) through the distance education model and other digital materials. The research was designed as pretest-posttest with the control group in an experimental design.The experimental group was applied 40 minutes of exercise 3 days a week for 6 weeks. The exercises were transferred to the experimental group via online applications. In the study, "Attention Deficit and Hyperactivity Disorder Self-Assessment Scale for Children (10-14 Age Group)" was used as a data collection tool to determine students' attention deficits and "Exam Anxiety Inventory" was used to determine test anxiety. The scales were completed by the students through the links created by "Google Forms". Finally, it was seen that the exercise activities applied revealed a significant factor in reducing the attention deficit and exam anxiety of the 8th-grade students who are preparing for the LGS exam through distance education in digital environments during the Covid-19 process.

perceptions to other stimuli (Avanoglu et al., 2020). On the other hand, attention deficit is a negative situation that affects activities related to learning (Aslan et al., 2020), which, also plays a direct role in social and daily activities unlike the developmental level (APA, 2013).

Anxiety is defined as an unpleasant emotional state arising as a result of anxiety, stress, negative situations that lead the individual to restlessness, anxiety, or negative situations (Sielberg \& Vagg, 1995; Isik, 1996). Exam anxiety is defined as a situation that affects the performance of an individual concerning cognitive, sensual and behavioral aspects in situations where there is an exam or an evaluation (Zeidner, 1998), and about academic success (Gençdogan, 2006) and which causes certain negative situations if it is below or above a certain level (Musch \& Broder, 1999). According to the Turkish Psychiatric Association (2019), ali as per the need and target (Gallahue, 1982), focusi on only one stimulus despite many stimuli, and turning off

*Corresponding Author: emrah.secer@erzincan.edu.tr 
this negative situation that started before the exam or evaluation and continues afterward is among the important factors that prevent the use of the learned information.

Covid-19 virus, which started in the city of Wuhan in China, spread rapidly all over the world with its highly contagious feature (Everett et al., 2020), has become a global threat (Cao et al., 2020). For this reason, many countries have started to take measures such as curfew and social distance (Andrews et al., 2020). The first case in Turkey was detected on the 11th of March and at the first stage a holiday for 14 days was announced for schools and universities affiliated with the Ministry of National Education and afterward, it was passed on to distant education. As of March 16, 2020, education and training in primary, secondary, high schools, and universities have been suspended and distance education has been initiated (T.R.Ministry of Health, 2020). These restrictions have caused a sudden change in the daily lives of individuals and have affected their emotional states such as fear and anxiety in a negative way (Liu et al., 2020).

When the literature is examined, it is seen that exercise has positive effects on attention and academic achievement (Howie \& Pate, 2012), and it decreases anxiety when supported with recreational activities (Birtürk, 2014). As a matter of fact, in the study conducted by Demir \& Çiftçi (2020), they stated that those who exercised in the Covid-19 pandemic process in high school students were psychologically better than those who did not, that is, they experienced less anxiety. Besides, it is stated that studies on exam anxiety generally focus on university students, but there are few experimental studies in lower age groups, so experimental studies in lower age groups should be increased (Von-der Embse et al., 2013).

The purpose of this study is to determine the effect of exercise activities to be applied during the Covid-19 pandemic, which is experienced globally and negatively affects individuals, especially children preparing for the exam, on the attention deficit and exam anxiety of students preparing for the exam through distanceeducation.

In line with this purpose, problem situations of research are as follows;

-Is there a significant difference between the experimental group's attention deficit and exam anxiety pre-test scores and posttest scores?

-Is there a significant difference between the control group's attention deficit and exam anxiety pre-test scores and posttest scores?

-As a result of the exercise program applied, is there a significant difference between the attention deficit post-test mean scores of the experimental and control groups?

-As a result of the applied exercise program, is there a significant difference between the test anxiety posttest score averages of the experimental and control groups?

Methodology:

This research is an experimental study. This model is a two- factor experimental design showing repeated measures (pretest-posttest) and subjects in different categories (experiment-control) (Büyüköztürk, 2016).

Pretest-Posttest Design with control group

Groups Pretest Process Posttest

Experiment gr. Attention scale-SKE Exercise activities Attention scale-SKE Control group Attention scale-SKE ----- Attention scale-SKE

The study group consists of 50 ( 25 experimental - 25 control) students who are actively studying in a secondary school in the center of Erzincan and preparing for the exam. However, during the research process, some participants were excluded from the study for various reasons and the study was terminated with 42 (21 experimental-21 control) participants.

Table 1: Distribution of Experimental and Control Groups by Gender and Average Values of Age Variables

Variable $n$ Woman Man Age/ Age/ $\mathrm{X}_{ \pm} \mathrm{Ss}$

Min-Max

$\begin{array}{llllll}\text { Experimentgroup } & 21 & 11 & 10 & 13-15 & 13.62 \pm .59\end{array}$

$\begin{array}{llllll}\text { Controlgroup } & 21 & 11 & 10 & 12-15 & 13.62 \pm .66\end{array}$

$\begin{array}{llllll}\text { Total } & 42 & 22 & 20 & 12-15 & 13.62 \pm .62\end{array}$

"Personal Information Form" created by researchers is a 4-point Likert type scale in the form of "Attention Deficit and Hyperactivity Disorder Self-Assessment Scale for Children (10-14 Age Group)" developed by Kanat (2019); 3 sub-dimensions (Impulsivity, Excessive Mobility, and Attention Deficit) consisting of 24 items (Almost neverSometimes-Often and Very often). In the study, only the attention deficit sub-dimension of this scale was used and the Cronbach Alpha coefficient was calculated $a=.75$ for the post-test.

In order to determine exam anxiety situations, the "Exam Anxiety Inventory (TAI)", a psychometric scale using the self-assessment method, was used by Spielberger \& Vagg (1975). The adaptation of the inventory to Turkish was carried out by Oner \& Albayrak Kaymak (1990). The scale consists of two sub-dimensions and 20 items, and they express the anxiety that the students feel intensely before, during, and after the exam with a 4 -grade scale in the inventory. In the inventory, there are three types of scores: the Whole test score (TAI-T), the subtests of the inventory, the Delusion subtest (AQI-K), and the Affinity subtest (TAI-D). In this study, processes were carried out on the whole test score of the scale. The Cronbach Alpha coefficient of the scale was calculated $a=.90$.

It is stated that if the reliability coefficient is .80 and above, the scale is reliable and the items are suitable for measuring the same behavior, and if it is between .60-.8o, it is at an acceptable level (Kalayci, 2018).

Due to the Covid-19 pandemic process,, we are in, the scales applied were implemented to the research group via Google forms. The research was conducted in the second term of the 2019-2020 academic year between 1 May 2020 - 15 June 2020. 
Table 2: Skewness-Kurtosis values and Kolmogorov-Smirnov Normality results regarding the Pre-test and Post-test Scores of the Experimental and Control Groups

\begin{tabular}{|c|c|c|c|c|c|c|c|c|c|c|}
\hline \multicolumn{3}{|c|}{ Group } & $\mathrm{n}$ & Min. & Max. & $\mathrm{X} \pm \mathrm{Ss}$ & Skewness & Kurtosis & KS test & $\mathrm{p}$ \\
\hline & Pretest & Attention deficit & 21 & $7 \cdot 00$ & 24.00 & $14.23 \pm .93$ & .505 & -.036 & .102 & $.20{ }^{\star}$ \\
\hline Еี & & Total exam anxiety & 21 & 21.00 & 77.00 & $51.19 \pm 2.74$ & -.337 & .493 & .173 & .102 \\
\hline$\cdot \frac{E}{d}$ & & Attention deficit & 21 & 7.00 & 21.00 & $11.90 \pm .79$ & .795 & .263 & .167 & .128 \\
\hline : & Posttest & Total exam anxiety & 21 & 27.00 & 72.00 & $45.00 \pm 2.91$ & $\cdot 731$ & -.364 & .170 & .116 \\
\hline I & Pretest & Attention deficit & 21 & 9.00 & 21.00 & $12.23 \pm .64$ & 1.257 & 2.549 & .151 & $.200 *$ \\
\hline $\bar{O}$ & & Total exam anxiety & 21 & 30.00 & 71.00 & $48.28 \pm 2.42$ & .440 & -.456 & .111 & $.200 *$ \\
\hline
\end{tabular}

While determining the exercise protocol used, it is seen that many universities, sports centers, coaches, municipalities, non-governmental organizations are making exercise recommendations within the scope of "stay at home but don't stay without sports" recommendations specific to the covid-19 process. In this study, in addition to exercise practices for children that can be done at home, which are published on youtube pages (https://www.youtube.com/watch?v=krdyeGlTP7g) Kocaeli Metropolitan Municipality and Kocaeli Guide Youth have made various activities to increase normal energy consumption levels. These activities, which were made by the experimental group, were carried out for 6 weeks, 3 days a week and 40 minutes each.

In addition to descriptive analyzes of the data such as frequency, arithmetic mean and standard deviation, dependent groups t test (paired t test) was used to compare the pretest-posttest scores of the experimental and control groups within the group. In addition, ANCOVA (Analysis of Covariance) analysis was used to test the efficiency of the experimental procedure and to make comparisons between groups. In the ANCOVA analysis, attention deficit and test anxiety variables were analyzed as separate models. In checking the suitability of the data for parametric tests, the skewness (skewness) and kurtosis (kurtosis) values and Levene test results (equality of variances) were examined for all variables (Buyukozturk, 2020). It was determined to be between skewness values (-.337 and 1.257) and kurtosis values (-.036 and 2.732) in relation to the distribution of attention deficit and test anxiety pre-test and post-test scores of the experimental and control groups. In addition, it is stated that it is appropriate to use parametric analysis if the skewness and kurtosis values are between -3 and +3 (Kalayci, 2018). In addition, in order to test the normality of the data, the results of the Kolmogorov-Smirnov (K-S) test were also examined since the number of data was 42 in the study. According to Demir et al., (2016), it is stated that the Kolmogorov-Smirnov test can be used if the sample size is larger than 35. It is stated that data shows normal distribution in case Kolmogorov-Smirnov test "Sig." Values are $\mathrm{p}=.05$ (Field, 2017). When the values related to the equality of regression lines between the common variable and the dependent variables, which are among the other prerequisites of ANCOVA analysis, are examined, it is seen that [Fgroup* pretest (attention deficit) $(1,38)=.948, \mathrm{p}=.336$ ] ve [Fgroup ${ }^{*}$ pretest (exam anxiety) $(1,38)=.000, p=.987$ ] regression lines were found to meet the equality condition.

The scores obtained from the attention deficit and test anxiety scales in the pre-test and post-test measurements showed a normal distribution in both the experimental and control groups. In addition, by examining the Levene test results, parametric analyzes were made by determining that the variances were homogeneously distributed (p>.05).

\section{Results:}

Table 3: Dependent groups t-test results for Experimental (Ex) and Control (Co) Groups ( $\mathrm{n}=21$ )

\begin{tabular}{|c|c|c|c|c|c|c|}
\hline \multicolumn{2}{|l|}{ Group } & $\mathrm{X}^{-}$ & Ss & $\mathrm{Sd}$ & $\mathrm{t}$ & $\mathrm{p}$ \\
\hline \multirow[t]{2}{*}{ Ex.-Attention deficit } & Pretest & 14.23 & 4.27 & 20 & 3.326 & $.003^{* *}$ \\
\hline & Posttest & 11.90 & 3.65 & & & \\
\hline \multirow[t]{2}{*}{ Total exam anxiety } & Pretest & 51.19 & 12.56 & 20 & 2.552 & $.019^{*}$ \\
\hline & Posttest & 45.00 & 13.34 & & & \\
\hline \multirow[t]{2}{*}{ Co.-Attention deficit } & Pretest & 12.23 & 2.94 & 20 & -4.459 & $.000^{* *}$ \\
\hline & Posttest & 14.47 & 4.19 & & & \\
\hline \multirow[t]{2}{*}{ Total exam anxiety } & Pretest & 48.28 & 11.12 & 20 & -2.416 & $.025^{*}$ \\
\hline & Posttest & 52.71 & 10.69 & & & \\
\hline
\end{tabular}

Statistically significant differences in the pre-test and post-test scores of attention deficit and exam anxiety level in relation to the students in the experimental group was evidenced. Accordingly, it was seen that the exercise program applied had a significant decrease in the attention deficit and exam anxiety levels of the students in the experimental group compared to the pre-test scores, and the exercise program applied produces very important results.

When the control group was examined, a statistically significant differences in the pre-test and post-test scores of attention deficit and exam anxiety level. However, unlike the experimental group, it was observed that the attention deficit and exam anxiety levels of the students in the control group significantly increased in the post-test scores compared to the pre-test scores, and the students experienced a negative process.

The average score of the experimental group $\left(\mathrm{X}^{-}: 11.12\right)$ was lower than the control group ( $\left.\mathrm{X}^{-}: 15.26\right)$. According to this result, ANCOVA test was conducted regarding the 
significance of the difference in attention-deficit points between the groups. It was determined that there is a significant difference between the posttest scores of the students in the experimental and control groups, which were corrected according to their pre-test scores. Accordingly, it was seen that the students in the experimental group experience fewer problems in terms of attention deficit at the end of the exercise applications. When the eta-square value was examined, it was determined that being in different groups explained $36.7 \%$ of the variability in the posttest scores (Table-4).

Table-4: ANCOVA Results on the Comparison of Attention Deficit Post-Test Scores of Experimental \& Control Group Students

\begin{tabular}{|c|c|c|c|c|c|c|}
\hline Group & $\mathrm{n}$ & \multicolumn{2}{|c|}{$\mathrm{X}^{-} \pm \mathrm{Ss}$} & \multicolumn{3}{|c|}{$\mathrm{X}^{-}$(corrected) } \\
\hline Experiment & 21 & \multicolumn{2}{|c|}{$11.90 \pm 3.65$} & \multicolumn{3}{|l|}{11.12} \\
\hline Control & 21 & \multicolumn{2}{|c|}{$14.47 \pm 4.19$} & \multicolumn{2}{|l|}{15.26} & \\
\hline Source of variance & $\mathrm{KT}$ & Sd & $\mathrm{KO}$ & $\mathrm{F}$ & $\mathrm{p}$ & ?p2 \\
\hline Model & 401.162 & 2 & 200.581 & 27.227 & .000 & .583 \\
\hline Pretest (Att. def.) & 331.733 & 1 & 331.733 & 45.029 & .000 & .073 \\
\hline Group & 166.934 & 1 & 166.934 & 22.660 & $.00{ }^{*}$ & .367 \\
\hline Error & $287 \cdot 314$ & 39 & $7 \cdot 367$ & & & \\
\hline Total & 7996 & 42 & & & & \\
\hline
\end{tabular}

Table 5: ANCOVA Results on the Comparison of Experimental and Control Group Students' Exam Anxiety Post-Test Scores

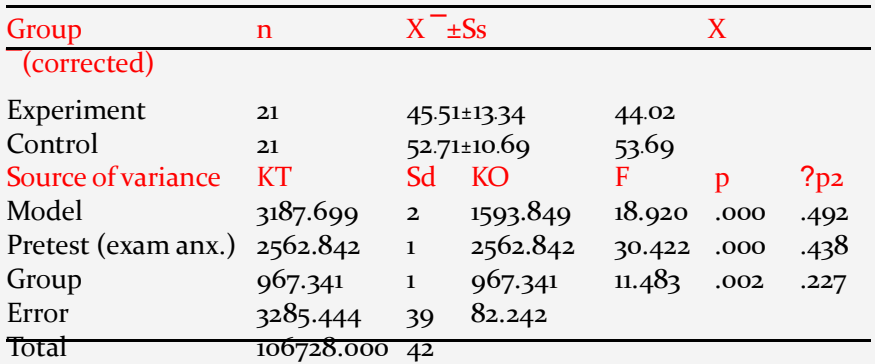

When the mean scores of the students' test anxiety corrected according to their pre-test scores are examined, it is seen that the experimental group mean scores $\left(\mathrm{X}^{-}: 44.02\right)$ were lower than the control group $\left(\mathrm{X}^{-}: 53.69\right)$. As per the analysis results, a significant difference between the posttest scores of the students in the experimental and control groups, which were corrected according to their pre-test scores. It was seen that the students in the experimental group experienced fewer problems in terms of test anxiety in the exercise applications compared to the control group. When the eta-squared value is examined, it is seen that being in different groups explains $22.7 \%$ of the variability in the posttest scores.

\section{Discussion and Conclusion:}

When the literature is examined, it is stated that exercise is a very important factor in eliminating or reducing attention deficits of children and adolescents, and it will produce very effective results when used with other intervention techniques (Tekin, 2020; Christiansen et al., 2019). In another study, it was stated that an exercise program enriched with cognitive stimuli had positive effects on cognitive flexibility and memory (Gentile et al., 2020), so it is thought that such exercises will positively affect attention performance. In the experimental study conducted by Mehren et al., (2020) it has been determined that exercise is very effective on attention deficit. Topçu, (2007) stated that folklore exercises applied for 15 weeks eliminate attention deficit and hyperactive disorders of children to a great extent and can be used as auxiliary activities in medical treatments.

In studies conducted in different countries (Shevlin et al., 2020; Moghanibashi-Mansourieh, 2020) and in our country (Özdin et al., 2020) during the Covid-19 pandemic process, it was found that individuals' anxiety levels were quite high. As a result of the closure of schools, individuals in societies, especially children, enter an irregular education process, so both families and children experience great anxiety (Daniel, 2020). It is stated that the anxiety state of children is significantly affected by socialization and maintaining close relationships as a result of communication with peers in schools. When the studies in the Covid-19 pandemic process were examined, it was emphasized that regular exercise positively affects the mood of individuals (Lades et al., 2020), contributes to the reduction of negative emotions such as stress (Simpson \& Katsanis, 2020), and home exercises reduce the experience of negative anxiety (Huang et al., 2020). Based on the results of this research, it is stated that cognitive and behavioral interventions in addition to relaxation techniques performed in 8th-grade students, where the entrance exams to high schools are held, are very important in reducing exam anxiety (Ergene, 2003). In the study where the impact of 12 weeks recreative event on anxiety was examined, including basketball, athletism and orienteering, and similar sports events, being conducted on children who will enter exams by Birtürk (2014), although there is no significant difference between the post-test scores of the experimental and control groups, it is determined that there is a significant increase between the pre-test and post-test scores of both groups, and the importance of planned recreational activities is emphasized. In the study by Bozkurt (2003), the importance of physical education activities in reducing anxiety before the exam is emphasized.

As a result, it is seen that the exercise activities applied are an important factor in reducing the attention deficit and exam anxiety of middle school 8th-grade students who are preparing for the LGS exam through distance education supported by digital platforms and materials during the Covid-19 pandemic process.

\section{Limitedness and suggestions:}

Due to the fact that the research was carried out during the process of the Covid-19 pandemic, data and exercise activities were realized through the internet, with only a limited number of participants and only a quantitative 


\section{ORIGINAL ARTICLE}

scale. Future studies are recommended to be conducted with a larger sample and different age categories. In addition, it is recommended to add qualified exercise activities to the distance education modules in order to reduce exam anxiety and to have a healthy mental and physical structure by considering the developmental periods of the students in parallel with the research results. It is recommended that all students be directed to exercise in cooperation with families and educational institutions.

\section{References:}

Andrews, J.L., Foulkes, L. \& Blakemore, S.J. (2020): Peer influence in adolescence: Public-Health implications for COVID-19. Trend. Cognit. Sci., 24(8):585-587.

Aslan, H., Aksoy, Y. \& Imamoglu, O. (2020): Ögrencilerde Spor Durumu Ve Yas Kategorisine Göre Dikkat Düzeylerinin Karsilastirilmasi. Turk. Stud., 15(2):729-738.

Avanoglu, E.A., Karakaya, H. \& Hazar, S. (2020): Fiziksel Aktivite Düzeyi Ile Dikkat Seviyesi Arasindaki Iliskinin Incelenmesi. Sivas Cumhuriyet Ünivers. Spor Bilimleri Dergisi, 1(1):10-15.

Birtürk, A. (2014): 12 Haftalik Rekreatif Etkinliklerin Seviye Belirleme Sinavina Girecek Ilkögretim Ögrencilerinin Durumluk ve Sürekli Kaygi Düzeyine Etkisi. Yüksek Lisans Tezi. Kocaeli Üniversitesi, Kocaeli.

Bozkurt, N. (2003): Üniversite Giris Sinavi. Çagdas Egitim Dergisi, 296:12-45.

Büyüköztürk, S. (2016): Deneysel Desenler: Ön test-son Test Kontrol Grubu Desen Ve Veri Analizi. Pub. by: Pegem Akademi Yayinlari, Ankara.

Büyüköztürk, S. (2020): Egitimde Bilimsel Arastirma Yöntemleri. Pub. by: Pegem Akademi Yayinlari, Ankara.

Cao, W., Fang, Z., Hou, G., Han, M., Xu, X., Dong, J. \& Zheng, J. (2020): The psychological impact of the COVID-19 epidemic on college students in China. Psychiat. Res., 112934.

Cecilia, A.E. \& Paul, H.D. (2020): Adolescent Addiction Epidemiology, Assessment, and Treatment A volume in Practical Resources for the Mental Health Professional II ed. Pub. by:. Academic Press.

Christiansen, L., Beck, M.M., Bilenberg, N., Wienecke, J., Astrup, A. \& Lundbye-Jensen, J. (2019): Effects of exercise on cognitive performance in children and adolescents with ADHD: Potential mechanisms and evidence-based recommendations. J. Clinic. Med., 8(6):841.

Daniel, S.J. (2020): Education and the COVID-19 pandemic. Prospects. 49: 91-96.

Demir, A. \& Çiftçi, F. (2020): Covid-19 Pandemi Sürecinde Egzersizin Lise Ögrencilerinin Psikolojik Saglamlik Düzeylerine Etkisinin Incelenmesi. Spormetre-J. Physic. Edu. Sport Sci., 18(3):169-179.

Demir, E., Saatçioglu, Ö. \& Imrol, F. (2016): Uluslararasi Dergilerde Yayimlanan Egitim Arastirmalarinin Normallik Varsayimlari Açisindan Incelenmesi. Curr. Res. Edu., 2(3):130-148.

Demirel, H.G. \& Cicioglu, H.I. (2020): Üst Düzey Sporcularin Egzersiz Bagimlilik Düzeylerinin Incelenmesi. Gaziantep Üniversitesi Spor Bilimleri Dergisi, 5(3):242-254.

Ergene, T. (2003): Effective Interventions on Test Anxiety
Ambient Science, 2020: Vol. 07(Sp1); 303-308 DOI:10.21276/ambi.2020.07.sp1.oa43

Reduction:A Meta-Analysis. Sch. Psychol. Int., 24(3):313-328.

Everett, J.A., Colombatto, C., Chituc, V., Brady, W.J. \& Crockett, M. (2020): The effectiveness of moral messages on public health behavioral intentions during the COVID-19 pandemic (https://psyarxiv.com/9yqs8/).

Field, A. (2017): Discovering Statistics Using SPSS (Five Edition). Pub. by: London: SAGE Press.

Gallahue, L.D. (1982): Developmental movement experiences for children Newyork. Pub. by: Machillan Publishing Company.

Gençdogan, B. (2006): Lise Ögrencilerinin Sinav Kaygisi ile Boyun Egicilik Düzeyleri ve Sosyal Destek Algisi Arasindaki Iliskiler. Atatürk Üniversitesi Sosyal Bilimler Enstitüsü Dergisi, 7(1):153-164.

Gentile, A., Boca, S., Sahin, F.N., Güler, Ö., Pajaujiene, S., Indriuniene, V., Demetriou, Y., Sturm, D., Gómez-López, M., Bianco, A. \& Alesi, M. (2020): The Effect of an enriched sport program on children's executive functions: the ESA Program. Front. Psychol., 11:657.

Howie, E.K. \& Pate, R.R. (2012): Physical activity and academic achievement in children: A historical perspective. I. Sport Health Sci., 1:16o-169.

Huang, Y., Li, L., Gan, Y., Wang, C., Jiang, H., Cao, S. \& Lu, Z. (2020): Sedentary behaviors and risk of depression: A MetaAnalysis of prospective studies. Translat. Psychiat., 10(1):1-10.

Isik, E. (1996): Nevrozlar. Pub. by: Kent Matbaasi, Ankara.

Kalayci, S. (2018): SPSS Uygulamali Çok Degiskenli Istatistik Teknikleri (8. Baski). Pub. by: Detay Yayinlari, Ankara.

Kanat A. (2019): Çocuklar Için (10-14 Yas Grubu) Dikkat Eksikligi ve Hiperaktivite Bozuklugu Kendini Degerlendirme Ölçegi Güvenirlik ve Geçerlilik Çalismasi. Yüksek Lisans Tezi, Toros Üniversitesi, Mersin.

Lades, L., Laffan, K., Daly, M. \& Delaney, L. (2020): Daily Emotional Well-Being during the COVID-19 Pandemic. Br. J. Health Psychol. 10.1111/bjhp.12450.

Liu, N., Zhang, F., Wei, C., Jia, Y., Shang, Z., Sun, L. \& Liu, W. (2020): Prevalence and predictors of PTSS during COVID-19 outbreak in China Hardest-Hit areas: Gender differences matter. Psychiat. Res., 112921.

Mehren, A., Reichert, M., Coghill, D., Müller, H.O.H., Braun, N. \& Philipsen A. (2020): Physical exercise in attention deficit hyperactivity disorder - Evidence and implications for the treatment of borderline personality disorder. Borderline Personal Disord Emot Dysregul., 2020; 7: 1.

Meßler, C.F., Holmberg H.C. \& Sperlich, B. (2016): Multimodal therapy involving high-intensity interval training improves the physical fitness, motor skills, social behavior, and quality of life of boys with ADHD: A randomized controlled study. $L$. Atten. Disord., 24:1-7.

Moghanibashi-Mansourieh, A. (2020): Assessing the Anxiety Level of Iranian General Population during COVID-19 outbreak. Asian J. Psychiat., 102076.

Musch, J. \& Broder, A. (1999): Test anxiety versus academic skills. A comparison of two alternative models for predicting performance in a statistics exam. Br. J. Educ. Psychol., 69:105116. 
Öner, N. (1990): Sinav Kaygisi Envanteri El Kitabi. Pub. by: Istanbul:Yöret Yayinlari.

Özdin, S. \& Bayrak Özdin, S. (2020): Levels and predictors of anxiety, depression and health anxiety during COVID-19 pandemic in Turkish society: The importance of gender. Int. J. Social Psychiat., 0020764020927051.

Shevlin, M., McBride, O., Murphy, J., Miller, J.G., Hartman, T.K., Levita, L. \& Bennett, K.M. (2020): Anxiety, depression, traumatic stress, and COVID-19 related anxiety in the UK general population during the COVID-19 pandemic. BJPsych. Open. 6(6): e125.

Simpson, R.J. \& Katsanis, E. (2020): The immunological case for staying active during the COVID-19. Pandemic. Brain, Behavior, and Immunity. Brain Behav. Immun., 87: 6-7.

Spielberger, C.D. \& Vagg, P.R. (1995): Test Anxiety: Theory, Assessment, and Treatment. Pub. by: Washington: Taylor and Francis.

Saglik B.T.C. (2020): COVID-19 (Yeni Koronavirüs Hastaligi) Nedir? ( https://covid19.saglik.gov.tr/TR-66135/1-yenikoronavirus-sars-cov-2-nedir.html )
Tekin, A. (2020): Çocuk ve Ergenlerde Dikkat Eksikligi ve Hiperaktivite Bozuklugu Tedavisinde Fiziksel Egzersizin Islevi. Mod. Leisure Stud., 2(1):24-32.

Topçu, B., Yildiz, S. \& Bilgen, Z.T. (2007): Dikkat eksikligi hiperaktivite bozuklugu olan çocuklarda folklor egzersizinin etkisi. Genel. Tip. Derg., 17(2).

Türkiye Psikiyatri Dernegi. (2019): Sinav Kaygisi. (https://www.psikiyatri.org.tr/halka-yonelik/13/sinavkaygisi)

Von der Embse, N., Barterian, J. \& Segool, N. (2013): Test anxiety interventions for children and adolescents: A systematic review of treatment studies from 2000-2010. Psychol. Schools, 50(1):57-71.

Zeidner, M. (1998): Test anxiety: The state of the art. Pub. by: New York: Plenum. 